\title{
Some Recent Trends in Studies of Human Lymphoid Cells: B-Cells, Epstein-Barr Virus, and Transformation
}

\author{
J. Zeuthen and G. Klein
}

\section{A. Introduction}

In this brief review we will discuss some recent trends in work on regulatory mechanisms involved in the selective expression of differentiated markers in human B-cell lines as well as the types of controls involved in the expression and function of Epstein-Barr virus (EBV) associated markers in human cells. A problem of special interest in this connection is the relation of the expression of EBV functions to the expression of "transformation".

In man EBV is a lymphotropic herpesvirus (Epstein and Achong 1979). Its main target is the human B-lymphocyte (Jondal and Klein 1973), though EBV may be able to infect other cell types, provided that the membrane barrier is surpassed. EBV is known to be the causative agent of infectious mononucleosis (IM) (Henle and Henle 1979) and is associated with the two completely different human malignancies: African Burkitt's lymphoma (BL), i.e. malignant proliferation of B-cells (Fialkow et al. 1970), and nasopharyngeal carcinoma (NPC), i.e. malignant proliferation of epithelial carcinoma cells (Klein 1979). In both of these cases, the presence of the EBV genome is demonstrated by the presence of EBV DNA as well as by the presence of EBV-specific antigens. The case of NPC in itself indicates that cell types other than B-lymphocytes under the right conditions can be infected by EBV. In addition to in vitro transformed lymphoblastoid cell lines (LCL), a wide variety of B-cell lines of BL origin are available; so far it has not been possible to grow cell lines from NPC tumors.

\section{B. Lymphoid Cell Lines}

Infection of B-lymphocytes by EBV regularly leads to transformation ("immortalization") into LCL (Pope 1979). Normally, B-lymphocytes are transitory cells located within a chain of differentiation which proceeds from primitive stem cells toward mature, immunoglobulinsecreting end cells (i.e., plasma cells). EBV cannot infect either stem cells or plasma cells. Infection of B-lymphocytes is sharply restricted to surface immunoglobulin and complement (C3) receptor positive B-cells (Einhorn et al. 1978). The EBV receptor is closely related to, and perhaps identical with, the complement (C3) receptor on B-cells (Jondal et al. 1976). The cell lines of $\mathrm{BL}$ origin in contrast to uncloned LCL cells appear to represent clones of proliferating neoplastic cells (Van Furth et al. 1972; Fialkow et al. 1973; Béchet et al. 1974). In contrast to myeloma cell lines which represent the plasma cell type of differentiation and secrete immunoglobulin at a high rate (Matsuoka et al. 1968), BL-derived cell lines correspond to an intermediate step in B-cell differentiation and synthesize immunoglobulins, usually IgM, which are almost exclusively destined for plasma membrane integration (Klein et al. 1970; Eskeland and Klein 1971). LCL cells appear to represent a step which is intermediate between BL and myeloma cells, and immunoglobulin secretion is observed (Nilsson and Pontén 1975). Rosetting B-cells with antigen coated erythrocytes prior to in vitro EBV transformation has permitted the establishment of LCL clones that produce human monoclonal antihapten antibodies (Steinitz et al. 1977, 1978; Kozbor et al. 1979), anti-Rh (D) antibodies (Koskimies 1980), anti-strep- 
tococcal antibodies (Steinitz et al. 1979), and Rheumatoid Factor (IgM anti-IgG) (Steinitz et al., to be published).

In addition to immunoglobulin expression, other B-cell markers are useful in characterizing the state of differentiation of lymphoid cell lines. The $\mathrm{F}_{\mathrm{c}}$, complement (C3), and EBV receptors are fully expressed by $\mathrm{BL}$ cells, but their expression is decreased in LCL lines and absent on myeloma lines. Ia-like antigens are expressed by both BL and LCL cells, but their expression is decreased on myeloma cells. Insulin receptors are not expressed by typical BL cells but are expressed by LCL cells. These patterns of expression are related to the expression of these markers during the normal B-cell lineage (Nilsson 1978).

\section{Chromosome studies on LCL and BL Cell Lines}

All newly established LCL lines have been found to be normal diploid or to reflect the karyotype of the patient from which they were established. The lines studied have included LCL lines established spontaneously from blood of patients with acute IM (Jarvis et al. 1974) and leukemia (Hellriegel et al. 1977) as well as lines established from cord and adult peripheral blood by means of exogenous EBV or by cocultivation with X-irradiated EBVproducing cells (Jarvis et al. 1974; Hellriegel et al. 1977; Zech et al. 1976). In lines cultivated for longer times secondary changes towards aneuploidy are very often seen and gains appear to be more frequent than losses of chromosomes. Chromosome gains are not random, since trisomy is often found for chromosomes $3,7,8,9$, and 12 ; the trisomy 7 is particularly interesting, since it is found in both BL and non-BL lymphoma lines (Zech et al. 1976; Steel et al. 1977). Freshly established LCL lines from normal donors usually clone at low frequency $(<2 \%)$ and are nontumorigenic in nude mice, while some long-term cultivated lines were found to be tumorigenic in nude mice (Nilsson et al. 1977).

Most BL cell lines are aneuploid. The chromosome 14 marker, first detected by Manolov and Manolova (1972) in BL biopsy cells and BL cell lines, has subsequently been identified in all BL cell lines examined with only a few exceptions. The chromosome 14 marker was originally described as an extra band located at the end of the long arm of one chromosome $14(14 q+)$. Zech et al. (1976) were able to identify the translocation of a segment from the end of one of the long arms of chromosome 8 to chromosome 14 $[\mathrm{t}(8 ; 14)(\mathrm{q} 24 ; \mathrm{q} 32)$.]. Similar chromosome abnormalities have been identified in other malignant lymphomas, but here the donor chromosomes were often variable. The specificity of the $14 q+$ anomaly in BL has recently been questioned by Van Den Berghe et al. (1979), who found a $t(2 ; 8)(p 12 ; q 23)$ in a child with typical European BL, which points to the possibility that chromosome $8(8 \mathrm{q}-)$ may be more specific for the disease than the $14 q+$. Other chromosomal changes are often found in BL lines, such as trisomy 7 (Zech et al. 1976; Steel et al. 1977). Since this change is also found in long-term cultured LCL cells and a certain preferential retention of chromosome 7 has also been observed in hybrid cells where human chromosomes are lost, it is a possibility that these changes are selected for in tissue culture. In two BL lines (DAUDI and NAMALWA) a region in the long arm of one chromosome 15 was lost or translocated (Zech et al. 1976; Zeuthen et al. 1977). The deletion of this region ( $q 14-q 21)$ was associated with the complete absence of $\beta_{2}$-microglobulin (DAUDI) or a reduction (NAMALWA) (Zeuthen et al. 1977). The gene for $\beta_{2}$-microglobulin is located on chromosome 15 (Goodfellow et al. 1975), and the extent of this interstitial deletion agrees well with more recent regional mapping data (Oliver et al. 1978). The karyotype of DAUDI cells is interesting also in the sense that it shows no further changes than the del(15) chromosome and the $t(8 ; 14)$ marker from the normal diploid karyotype in contrast to other commonly used BL cell lines. In various mutant sublines of DAUDI we have found identical karyotypes with so far only one exception (DAUDI-ouab ${ }^{r}-$ TG $^{r}$ ) which in addition showed trisomy 7 as well as a $3 q+$ marker. The picture for other commonly used BL sublines (e.g., RAJI and NAMALWA) is much more complicated.

The EBV-negative lymphoma line BJAB, though reported to be derived from an African BL patient (Menezes et al. 1975), clearly lacks the $14 \mathrm{q}+$ marker; in this case the original diagnosis may be doubtful, however. The EBV-negative American BL line RAMOS (Klein et al. 1975) has a $14 q+$ marker (Klein 
et al. 1976). The BJAB cell line in contrast to RAMOS is nontumorigenic in nude mice and also clones with low efficiency in agarose. Interestingly, the relatively nontransformed phenotype of $\mathrm{BJAB}$ dominates in hybrids with the highly transformed RAJI line, since these are low tumorigenic and clone with low efficiency in agarose (I. Ernberg, B.C. Giovanella, J. Zeuthen, unpublished). The two different EBV-negative lines have been converted to EBV-positive sublines by infection with two different strains of EBV (B95-8 and P3HR-1) (Klein et al. 1976a; Fresen and Zur Hausen 1976; Steinitz and Klein 1975). The converted sublines did not differ from their parents with respect to surface immunoglobulin or $F_{c}$ receptors, but a significant increase in both $\mathrm{EBV}$ and complement (C3) receptors was observed (Klein et al. 1976a). All the EBV converted sublines have shown an increasingly transformed phenotype as evidenced by increased resistance to saturation, decreased serum dependence, decreased capping of surface markers, increased lectin agglutinability, and an increased ability to activate the alternative complement pathway (Steinitz and Klein 1975, 1976, 1977; Yefenof and Klein 1976; McConnell et al. 1978; Yefenof et al. 1977; Montagnier and Gruest 1979). Analyses of the karyotypes of the EBV converted lines as compared to their EBV negative parents do not indicate any consistent chromosomal changes which could explain their changed growth characteristics.

The precise role of chromosome 14 anomalies in the development of lymphomas in unknown, but it has been suggested that the rearrangement of the distal part of the long arm somehow can be advantageous for the lymphoid cells during the suggested stepwise development of an autonomous BL clone (Zech et al. 1976). This suggestion is supported by the finding of rearrangements of chromosome 14 in ataxia telangiectasia (AT), a hereditary disease associated with increased chromosome breakage as well as lymphoid neoplasia (McCaw et al. 1975). Most AT patients have clones marked by a translocation involving chromosome 14 . The breaks observed in chromosome 14 have always been in the long arm at the q11-q12 region, and the other chromosomes involved in the translocations observed have been chromosomes $7,8,14$, and $\mathrm{X}$. Chromosome 14 rearrangements are found in varying proportions $(2 \%-5 \%)$ in lymphocy- tes, and breakage and chromosome 14 rearrangements are highly reduced in EBV-transformed LCL lines (Cohen et al. 1979). LCL lines derived from AT patients clone at slightly increased frequencies compared to lines from normal individuals or AT carriers. By successive cloning of an AT-derived LCL lines, subclones cloning at high efficiency which are also tumorigenic in nude mice were isolated, but we have not been able to correlate this secondary change with specific chromosomal changes (I. Ernberg et al., unpublished work). It is, however, possible that in vivo selected tumorigenic subclones could show specific canges.

The individuality of the different $\mathrm{BL}$ lines with respect to chromosome markers have proven of great value for our work on the characterization of different hybrid cell lines obtained by fusion of BL cells. The regular presence of these markers in the parental cells and their hybrids has made it possible to identify hybrid cells by detailed chromosome analysis. An example of the identification of a typical hybrid cell (in this case DAUDI/ P3HR-1) (Ber et al. 1978) is indicated in Fig. 1.

\section{Studies with Hybrid Cells}

In hybrids between the two BL derived cell lines RAJI and NAMALWA (Rosén et al. 1977), which express either small amounts of IgM $\varkappa($ RAJI) or large amounts of IgM $\lambda$ (NAMALWA) it was possible to quantitate the amounts of the two different types of light chains produced by the hybrid by means of radioimmunoassay. In spite of some variability between various clones tested, it appears that the hybrids expressed the same level of $x$ and $\lambda$ light chains as expressed by the parents individually. We can conclude that the exclusion of one of the light chains $(\lambda$ or $x$ ) in $\mathrm{BL}$ cells probably does not operate through soluble repressing factors or activating substances, since the production of $x$ and $\lambda$ proceeded simultaneously and at fixed levels in the hybrid clones. The event of allelic exclusion has presumably already taken place by the programming of the genome (i.e., the $\mathrm{V}-\mathrm{C}$ joining step) and has taken place on only one of the two homologous chromosomes for each immunoglobulin gene family (Bernard et al. 1978). In subsequent studies the analysis of immunoglobulin gene expression was extended to 


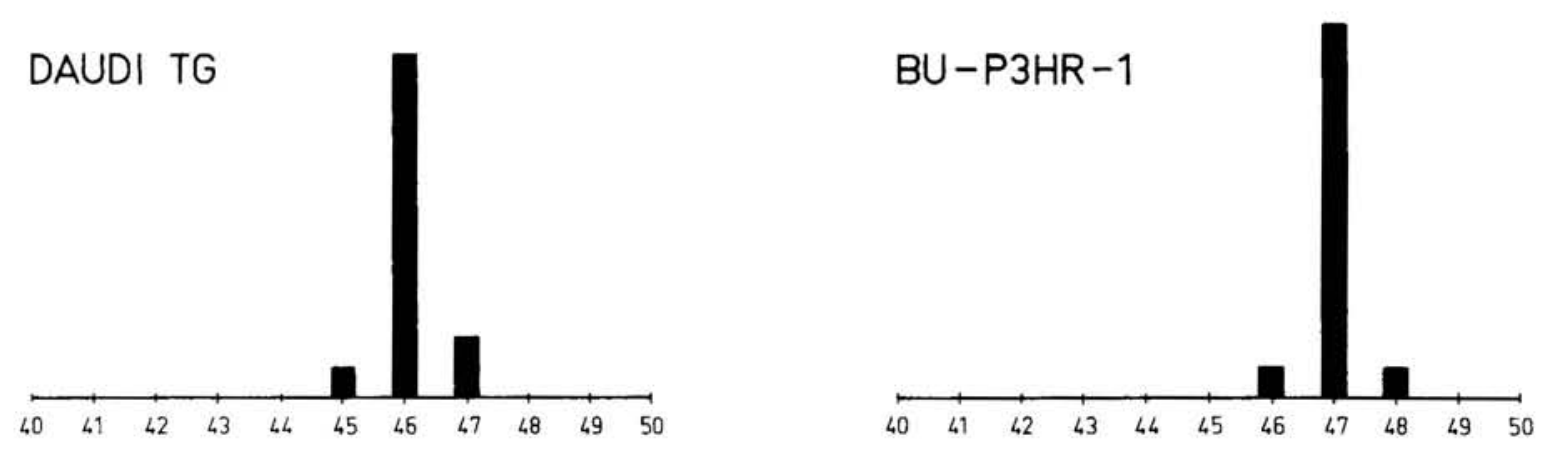

DIP-1
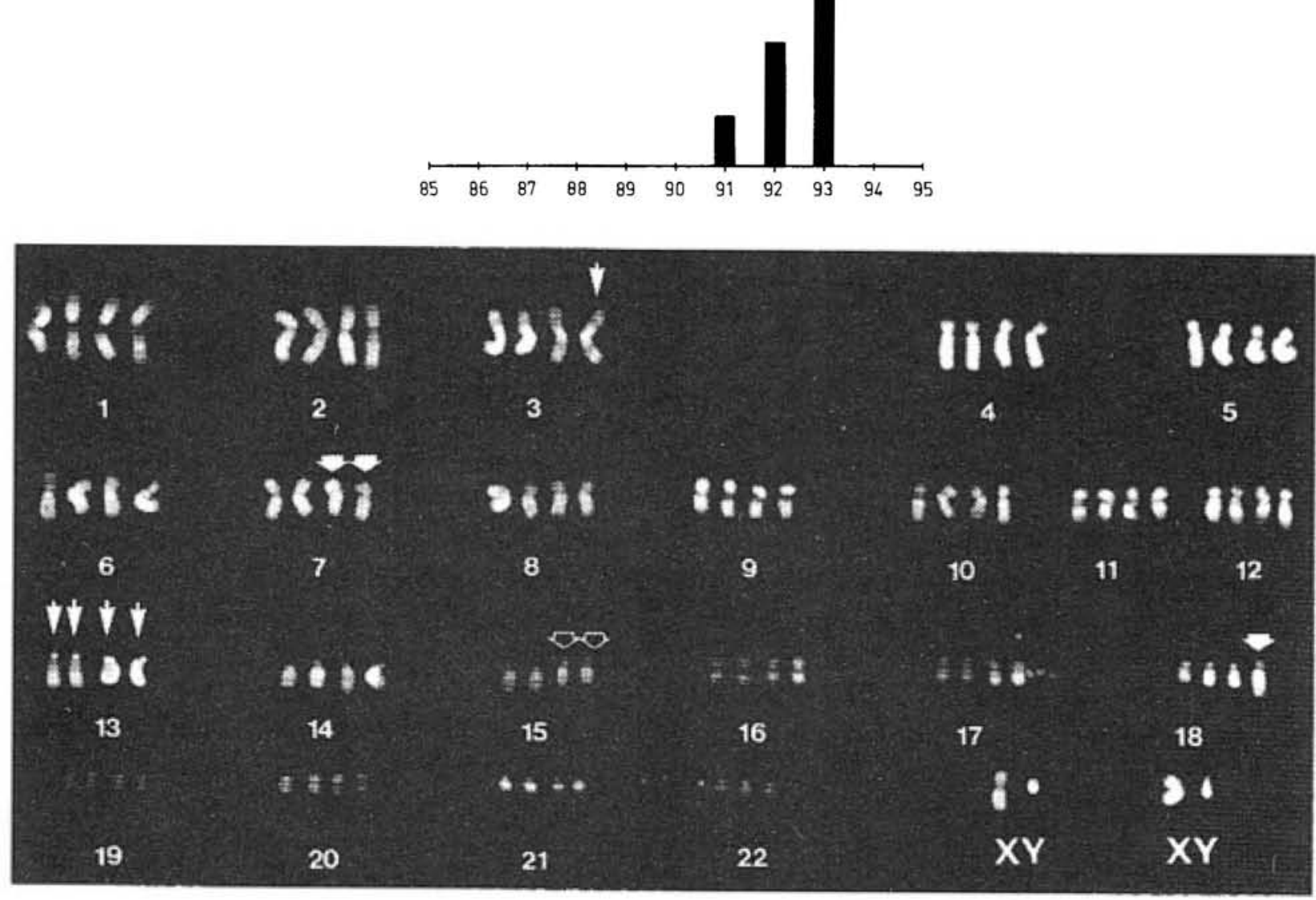

Fig. 1. Distribution of chromosome numbers in metaphases from two BL parental cell variants [ $D A U D I-T G$ (HPRT-) and $B U-P 3 H R-1$ (TK-)] and the hybrid (DIP-1) derived by fusion and selection of hybrids on selective HAT medium (selecting against growth of the two parents). The DIP-1 hybrid modal chromosome number is the sum of the two parents. Below is shown the karyogram of the DIP-1 hybrid. Marker chromosomes from the DAUDI-TG line are indicated by 33 , marker chromosomes from BU-P3HR-1 by , and chromosome 3 and 13 markers by $\downarrow$. (From Ber et al. 1978), by permission from the International Union Against Cancer)

other hybrid combinations. Two hybrids, RAJI/DAUDI (8A) and RAJI/BJAB, showed more complex features than observed previously (Klein et al. 1977b), while DAUDI/ P3HR-1 (Ber et al. 1978) was similar to the DAUDI parent. The RAJI/DAUDI (8A) hybrid showed a pronounced suppression of surface and intracellular immunoglobulin synthesis with amounts of $\mu$ and $x$ chains similar to the low-level expressing RAJI parent (Klein et al. 1977b). The DAUDI line has an unusual structure of its $8 \mathrm{~S}$ surface IgM, with an associated extra band of 33,000 daltons present in addition to the 23,500 and 75,000 
dalton bands corresponding to light and heavy chains, respectively (Singer and Williamson 1979). The 33K component has been suggested to be an Ia antigen, covalently bound to $\mu$ chains (Singer and Williamson 1979). A possibility is that the RAJI parent interferes with the assembly of this structure and makes it impossible for the DAUDI structure $(\mu+x+\mathrm{Ia})$ to integrate properly into the plasma membrane. A related possibility would be that the RAJI parent, being closer to the pre-B cell stage, "extinguishes" the high degree of differentiation of DAUDI cells. However, our recent results on another RAJI/DAUDI hybrid (DITRUD) of a different derivation gave conflicting results from those obtained with our first RAJI/DAUDI hybrid, since here IgM and $\varkappa$ chains were expressed at almost as high a level as for DAUDI on the cell surface (Zeuthen et al., to be published). An illustration of the expression of surface IgM analyzed by means of flow microfluorimetry is given in Fig. 2. To understand this difference, it must be born in mind that the first ( $8 \mathrm{~A}$ ) hybrid was isolated as adherent cells on selective HAT medium, since the RAJI parent used was both adherent and HPRT- (Allan and Harrison 1980), and the second (DITRUD) was isolated in suspension after fusion of DAUDI (HPRT-) and RAJI (TK-) cells (Zeuthen et al., to be published). Recent results have indicated that the cell shape is correlated with the expression of the differentiated phenotype (Allan and Harrison 1980), and a likely possibility is, therefore, that the selection of adherent cells in our first fusions has worked against the full expression of the differentiated marker (in this case surface $\operatorname{IgM} \varkappa$ ).

In hybrids of lymphoid cells with cells of other differentiation lineages immunoglobulin synthesis may be totally extinguished (Zeuthen and Nilsson 1976). We, therefore, found it of interest to investigate whether hybrids of $\mathrm{BL}$ cells with other hematopoietic cells would show the same type of restriction. A hybrid between the human erythroleukemic cell line K562 [inducible for hemoglobin synthesis by haemin (Rutherford et al. 1979)], and

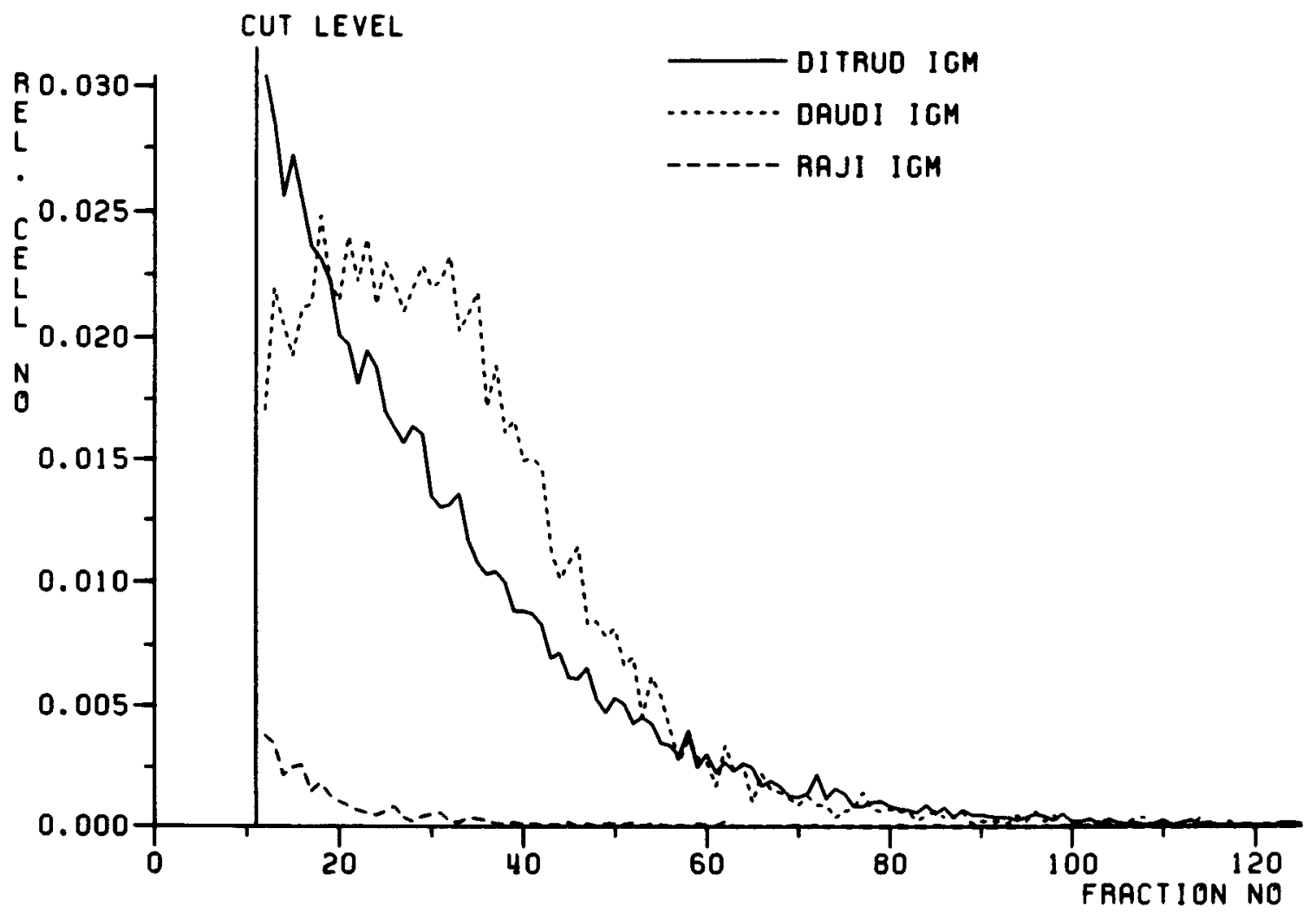

Fig. 2. An example of surface immunoglobulin expression on a RAJI/DAUDI hybrid [DITRUD, (Zeuthen et al., to be published)] and its two parental cells characterized by means of flow microfluorimetry after surface immunoglobulin staining for IgM. The analysis was carried out by means of a fluorescence activated cell sorter (FACS) and evaluated by a computer program. Unspecifically stained cells (<cut level) have been left out, and the percentages of cells above this level were: $3.9 \%$ (RAJI), $79.5 \%$ (DAUDI), and 68.7\% (DITRUD). For discussion see text 
P3HR-1 (Klein et al. 1980) showed a complete suppression of EBV receptors, and a DAUDI/ K562 hybrid showed a complete suppression of surface IgM in addition to other lymphoid markers (Zeuthen et al., to be published). Both of these two hybrid combinations had similarly high levels of heme as the K562 parent and were inducible for hemoglobin synthesis by addition of hemin. An example of the induction of hemoglobin-positive cells stained by benzidine is illustrated in Fig. 3 . These results indicate a relative dominance of erythroid differentiation at the expense of lymphoid differentiation in the hybrids of $\mathrm{BL}$ cells with the K562 line, which in many respects behaves like a relatively undifferentiated stem cell line. An additional hybrid between the human promyelocytic leukemic cell line HL 60 (Collins et al. 1977) and P3HR-1 (HP-1) was isolated recently (Koeffler, personal communication) and shows retention of B-cell Ia antigens but loss of the myeloid markers that characterize the HL-60 parent. In comparison with K562, HL-60 is more differentiated, and this might explain the fact that a reverse pattern of loss of differentiation is seen in this case.

In contrast to differentiated markers, the cellular "household" functions are usually

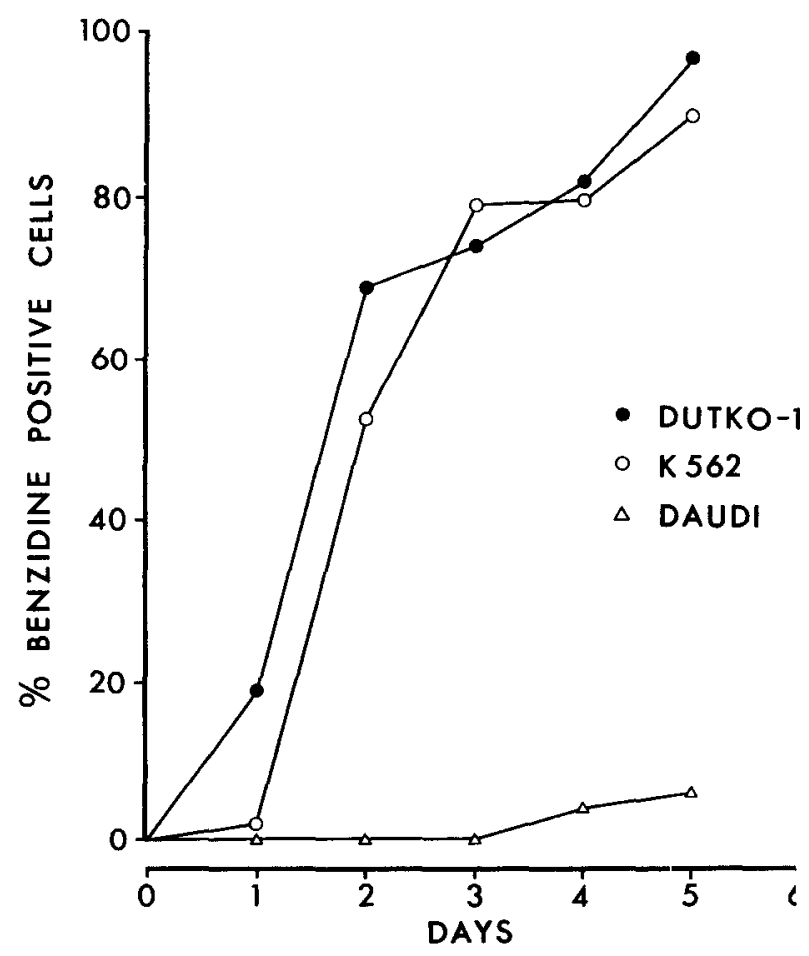

Fig. 3. Induction of benzidine-positive cells by 0.1 $\mathrm{mM}$ hemin in cultures of DAUDI, K562, and their hybrid (DUTKO) (Zeuthen et al., to be published). For discussion see text coexpressed in cell hybrids. This has been the case for isoenzyme markers, which in addition to our chromosomal characterization have been a useful tool in the identification of hybrid cells. One curious deficiency of BL cells is a loss of soluble malic enzyme $\left(\mathrm{ME}_{\mathrm{S}}\right)$, though this enzyme is expressed by other cell types (Povey et al., to be published). $\mathrm{ME}_{\mathrm{S}}$ is re-expressed in hybrids of BL cells with mouse fibroblasts and in the two hybrids with K562.

The HLA specificities of the parental cells are coexpressed in hybrids. A special case here is the hybrids with DAUDI cells ( $\beta_{2}$-microglobulin and HLA negative), where we found expression of completely new HLA specificities (A10,B38,B17) (Klein et al. 1977b; Fellous et al. 1977). We have interpreted this observation to indicate genetic complementation of the $\beta_{2}$-microglobulin deficiency of DAUDI to bring out its hidden HLA specificities in the form of new $\beta_{2}$-microglobulin-HLA dimer molecules on the cell membrane. The K562 line shows a similar lack of surface expressed HLA and $\beta_{2}$-microglobulin to DAUDI, though its intracellular content of $\beta_{2}$-microglobulin is normal (Zeuthen et al. 1977). This membrane defect is partially dominant in the P3HR-1/K562 hybrid (Klein et al. 1980), since only one P3HR-1 derived specificity (HLA-A3) could be detected in low amounts on the hybrid. In spite of this, complementation of the two kinds of defects were observed in the DAUDI/K562 hybrid by the expression of low amounts of HLA-B17, one of the "hidden" specificities characteristic of DAUDI cells (Zeuthen et al., to be published). A direct analysis of solubilized membrane proteins from this hybrid by crossed radioimmunoelectrophoresis (Plesner 1978) confirmed the presence of $\beta_{2}$-microglobulin-HLA dimer molecules in low concentration.

\section{E. Expression of EBV, the EBNA Antigen, and Transformation}

Multiple copies of EBV viral genomes are present in EBV-carrying cells of both BL and LCL origin (Adams 1979). These cells invariably contain the EBV-determined nuclear antigen EBNA (Reedman and Klein 1973). While EBNA is always expressed if the EBV genome is present, the early antigens (EA) and viral capsid antigens (VCA) are only expressed during the lytic cycle (Ernberg and Klein 
1979). The EBV-carrying cell lines can be classified into three cathegories: nonproducers (EBNA +, EA-, VCA-), abortive producers (EBNA,$+ \mathrm{EA}+, \mathrm{VCA}-$ ), and finally producers (EBNA,$+ \mathrm{EA}+, \mathrm{VCA}+$ ). The number of cells entering the lytic cycle can be amplified by inducers (IUdR, Na-butyrate, TPA) whose only common denominator is a known effect on differentiation in a variety of cell systems. Abortive producers such as RAJI switch on EA production in a small proportion of cells, but these do not proceed further to viral DNA synthesis and VCA production (Gergely et al. 1971). The block in the abortive producer cell lines could either be due to viral defectiveness or to negative cellular controls. The latter is more likely, since we have recently found that hybridization of RAJI with $\mathrm{BJAB}$ lifts the block to viral DNA replication and subsequent VCA production.

Other combinations in cell hybrids have given us further information with respect to the types of controls involved. With certain minor variations, the picture is consistent: When producer BL lines are fused with nonproducers, producer status tends to dominate over nonproducer status and inducibility over noninducibility (Ber et al. 1978; Nyormoi et al. 1973; Klein et al. 1976b, 1977b; Moar et al. 1978). This suggests that the controls appear to be of a positive nature. The results on the RAJI/BJAB hybrid and the observation that inducers used interfere with differentiation, while standard mutagenic or carcinogenic agents are noninducers (Zur Hausen et al. 1979), strongly suggests that the controls are cellular rather than viral.

It is of interest that EBV production and inducibility in many cases parallel the behavior of other B-cell markers in cell hybrids. In the cases where BL cells were hybridized with fibroblasts, virus production and inducibility were switched off in spite of the continued presence of EBV-DNA in multiple genome copies per cell and uninfluenced expression of EBNA (Klein et al. 1974; Glaser et al. 1977). In the P3HR-1/K562 hybrid a similar complete block against EA and VCA inducibility was observed using the three inducers IUdR, Na-butyrate and TPA (Klein et al. 1980). The DAUDI/K562 hybrid (Zeuthen et al., to be published), however, was inducible, probably due to a higher number of EBV copies.

An exception to the rule of extinction of EBV inducibility in hybrids of BL cells with other lineages are hybrids with human carcinoma cells (Glaser and Rapp 1972; Glaser and Nonoyama 1973; Tanaka et al. 1977; Baron and Strominger 1978), were the hybrids were completely permissive. This observation might be of some relevance to NPC, since epithelial carcinoma cells might be more compatible with EBV production than other human cells of non-B-cell origin.

Like the $T$ antigens of the small DNA viruses, EBNA is a DNA binding protein (Lenoir et al. 1976; Luka et al. 1977, 1978, to be published). Purified EBNA antigen has a molecular weight of $\sim 180,000$ daltons and consists of two major components of 48,000 and 53,000 daltons (Luka et al., to be published). While the $48 \mathrm{~K}$ component is probably virus coded, the $53 \mathrm{~K}$ component is also found in EBV-negative lymphoma lines, but not in T-cell derived cell lines. It is, therefore, possible that the $53 \mathrm{~K}$ protein is a nuclear protein characteristic of malignant B-cells. A similar $53 \mathrm{~K}$ component has been found in SV40 $\mathrm{T}$ antigen (McCormick and Harlow 1980), suggesting a further analogy between EBV and the much smaller papovaviruses. In recent experiments we have used fusion of EBNA loaded erythrocyte ghosts with quiescent cells to "microinject" (Klein et al. 1980, Zeuthen, unpublished work). In these experiments a stimulation of cellular DNA synthesis was observed to occur after microinjection (Fig. 4). In experiments with the isolated $48 \mathrm{~K}$ and $53 \mathrm{~K}$ components, the $53 \mathrm{~K}$ component appears to have this activity. These observations are similar to the stimulation of DNA synthesis in quiescent cells after microinjection of the SV40 $\mathrm{T}$ antigen (Tjian et al. 1978).

A quantitative relation between SV40 T antigen levels and viral late gene expression was recently described (Graessmann et al. 1978): SV40-infected cells with levels of $\mathrm{T}$ antigen above a certain treshold value expressed late viral genes. An interpretation of this observation is that an excess of $\mathrm{T}$ antigen is required to saturate binding sites on cellular DNA and in addition provide sufficient molecules to initiate DNA replication (and late gene expression). A similar mechanism could perhaps control the induction of viral DNA synthesis and VCA production in BL cells. Measurements by immunofluorimetry of EBNA in induced cultures of RAJI, DAUDI, and P3HR-1 cells show that EBNA immunofluorescence after induction is doubled after induction in the 


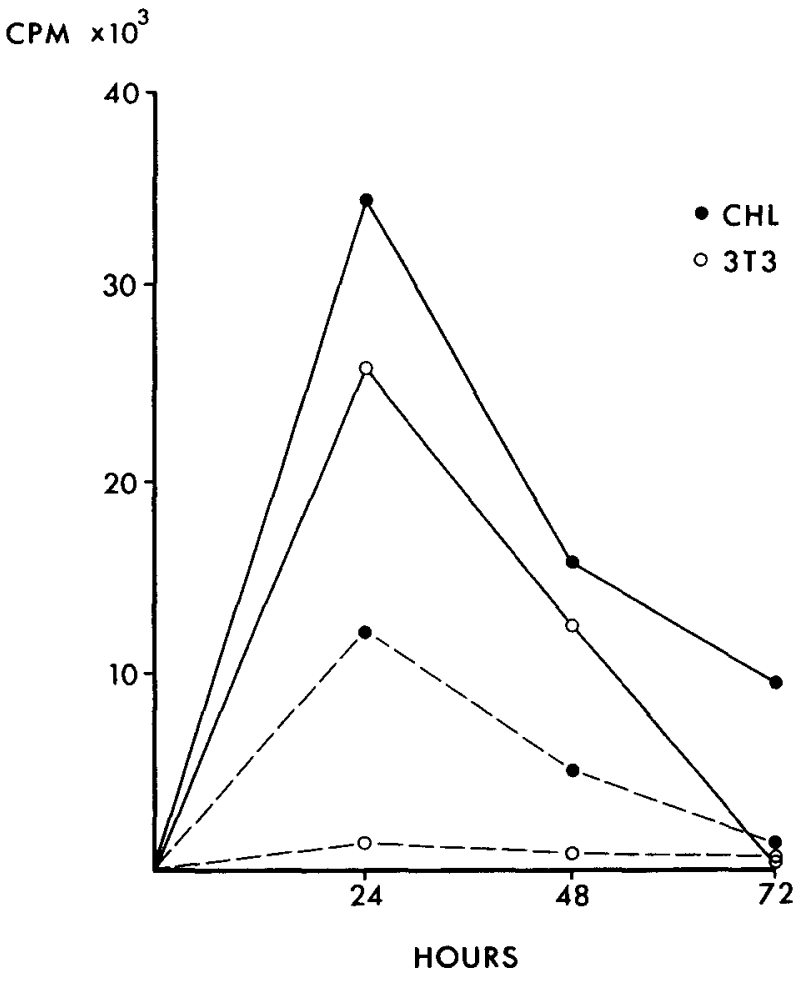

(1)
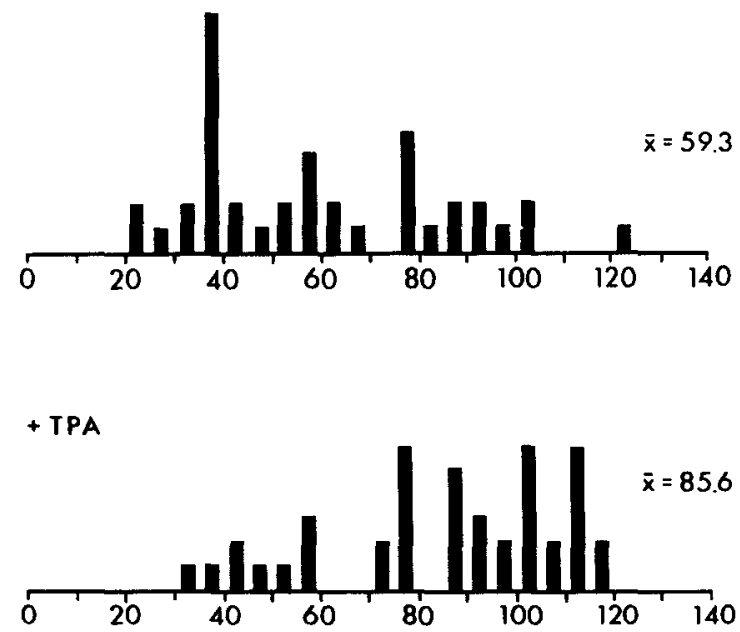

+ BUT

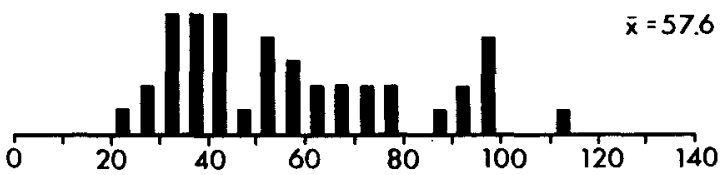

Fig. 4. Stimulation of the rates of DNA synthesis in contact-inhibited monolayers of primary chinese hamster lung $(C H L)$ cells and in monolayers of mouse 3T3 cells after erythrocyte ghost mediated microinjection of purified EBNA antigen. Rates of DNA synthesis were followed by pulse labeling of replicate slides with $1 \mathrm{uC}_{\mathrm{i}} / \mathrm{ml}\left({ }^{3} \mathrm{H}\right)$-thymidine for $2 \mathrm{~h}$ for each time point. Solid lines indicate cultures microinjected with EBNA, broken lines cells microinjected with a mock preparation (HMG proteins from EBV-negative cells). (Zeuthen, unpublished work)

Fig. 5. Quantitative immunofluorimetric measurements of EBNA immunofluorescence stained (Reedman and Klein 1973) slides prepared from control, TPA, and Na-butyrate induced cultures of DAUDI cells, 1 and 3 days after start of the experiment. In the induced cultures the average immunofluorescence values approximately double; this effect was not observed with the abortive producer RAJI line (Zeuthen and Ernberg, unpublished work). For discussion see text 
producer lines (DAUDI and P3HR-1), but in fact reduced for the abortive producer RAJI line (Zeuthen and Ernberg, unpublished work). These observations could indicate a role of EBNA in the control of viral DNA synthesis and could possibly indicate a defect in RAJI cells responsible for its abortive producer status. An example of these measurements is shown in Fig. 5.

Microinjection by capillaries has been used in attempts to infect cells that lack EBV receptors with EBV-DNA or EBV viral particles. In experiments where fibroblasts were injected with P3HR-1 EBV-DNA, cells were induced to produce EA (Graessmann et al. 1980). Using a similar technique, we injected human amnion epithelial cells with a $100 \times$ concentrated supernatant of B95-8 cells and found $50 \%-100 \%$ of the injected cells to become positive for EBNA (Zeuthen J, Rosenbaum S, Sørensen ET, unpublished) (Fig. 6).
Only a few batches of concentrated B95-8 viruses were effective in inducing EBNA, probably due to the limiting concentration of EBV particles. Attempts to select for growth of EBNA positive cells by further cultivation were unsuccesful and the infection achieved by microinjection of EBV in amnion epithelial cells can possibly be abortive.

\section{Acknowledgements}

We thank our colleagues for stimulating collaboration, discussions, and exchange of information. It will be evident from this article that without this it would have been impossible to collect the data. The projects have been generously supported by the Danish Cancer Society, the Danish Natural Science Research Council, Contract No. N01 CP 33316 from the Division of Cancer Cause and Prevention, National Cancer Institute, Public Health Service Reserach Grant No. 55R01 CA 14054-05, and the Swedish Cancer Society.

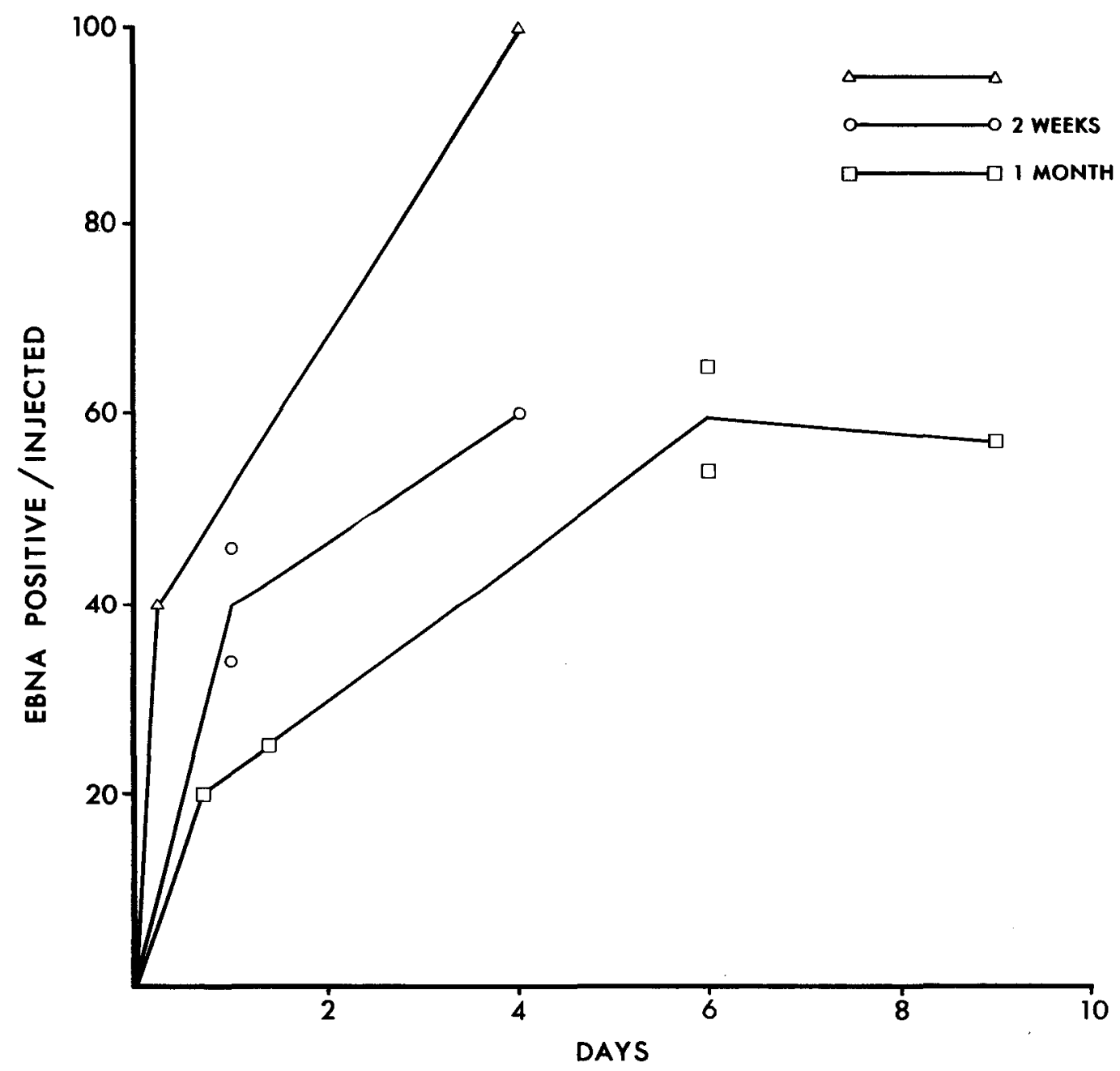

Fig. 6. Appearance of EBNA positive human amnion epithelial cells after microinjection by microcapillaries of a $100 \times$ concentrated supernatant of B95-8 cells (inducing 10\% EBNA positive RAMOS (EBV-negative) cells at $1: 320$ dilution) in three successive experiments with the same preparation of B95-8 stored for various times $\left(0,2\right.$ weeks and 1 month) at $4^{\circ} \mathrm{C}$. (Zeuthen et al., unpublished) 


\section{References}

Adams A (1979) The state of the virus genome in transformed cells and its relationship to host cell DNA. In: Epstein MA, Achong BG (eds) The Epstein-Barr virus. Springer, Berlin, p 155 - Allan M, Harrison P (1980) Co-expression of differentiation markers in hybrids between Friend cells and lymphoid cells and the influence of cell shape. Cell 19:437 - Baron D, Strominger JL (1978) Partial purification and properties of the Epstein-Barr virus - associated nuclear antigen. J Biol Chem 253:2875 - Béchet JM, Fialkow RJ, Nilsson K, Klein G (1974) Immunoglobulin synthesis and glucose-6-phosphate dehydrogenase as cell markers in human lymphoblastoid cell lines. Exp Cell Res 89:275 - Ber R, Klein G, Moar M, Povey S, Rosén A, Westman A, Yefenof E, Zeuthen J (1978) Somatic cell hybrids between human lymphoma lines. IV. Establishment and characterization of a P3HR-1/DAUDI hybrid. Int J Cancer 21:707 - Bernard O, Hozumi N, Tonegawa S (1978) Sequences of mouse immunoglobulin light chain genes before and after somatic changes. Cell 15:1133 - Clements GB, Klein G, Povey S (1975) Production by EBV infection of an EBNA-positive subline from an EBNA-negative human lymphoma cell line without detectable EBV DNA. Int J Cancer 16:125 - Cohen MM, Sagi M, Ben-Zur Z, Schaap T, Voss R, Kohn G (1979) Ataxia telangiectasia: Chromosomal stability in continuous lymphoblastoid cell lines. Cytogenet Cell Genet 23:44 - Collins SJ, Gallo RC, Gallagher RE (1977) Continuous growth and differentiation of human myeloid leukaemic cells in suspension culture. Nature 270:347 - Einhorn L, Steinitz M, Yefenof E, Ernberg I, Bakacs T, Klein G (1978) Epstein-Barr virus (EBV) receptors complement receptors, and EBV infectability of different lymphocyte fractions of human peripheral blood. II. Epstein-Barr virus studies. Cell Immunol 35:43 - Epstein MA, Achong BG (1979) Discovery and general biology of the virus. In: Epstein MA, Achong BG (eds) The Epstein-Barr virus. Berlin, Springer, p 1 - Ernberg I, Klein G (1979) EB virus-induced antigens. In: The Epstein MA, Achong BG (eds) The Epstein-Barr virus. Springer, Berlin, p 39 - Eskeland T, Klein $E$ (1971) Isolation of 7S IgM and kappa chains from the surface membrane of tissue culture cells derived from a Burkitt lymphoma. J Immunol 107:1367 - Fellous M, Kamoun M, Wiels J, Dausset J, Clements G, Zeuthen J, Klein G (1977) Induction of HLA expression in Daudi cells after cell fusion. Immunogenetics 5:423 - Fialkow PJ, Klein G, Gartler SM, Clifford P (1970) Clonal origin for individual Burkitt tumors. Lancet I;384 - Fialkow PJ, Klein E, Klein G, Clifford P, Singh S (1973) Immunoglobulin and glucose-6-phosphate dehydrogenase as markers of cellular origin in Burkitt lymphoma. J Exp Med 138:89 - Fresen KO, zur Hausen H (1976) Establishment of EBNA-expressing cell lines by infection of Epstein-Barr virus
(EBV)-genome-negative human lymphoma cells with different EBV strains. Int J Cancer 17:161 - Gergely L, Klein G, Ernberg I (1971) The action of DNA antagonists on Epstein-Barr virus (EBV)-associated early antigens (EA) in Burkitt lymphoma lines. Int J Cancer 7:293 - Glaser R, Nonoyama M (1973) Epstein-Barr virus: Detection of the genome in somatic cell hybrids of Burkitt lymphoblastoid cells. Science 179:492 - Glaser R, Rapp F (1972) Rescue of Epstein-Barr virus from somatic cell hybrids of Burkitt lymphoblastoid cells. J Virol 10:288 - Glaser R, Ablashi DV, Nonoyama M, Henle W, Easton J (1977) Enhanced oncogenic behavior of human and mouse cells after cellular hybridization with Burkitt tumor cells. Proc Natl Acad Sci USA 74:2574 - Goodfellow PN, Jones EA, van Heyningen V, Solomon E, Bobrow $M$, Miggiano V, Bodmer WP (1975) The $\beta_{2}$-microglobulin gene is on chromosome 15 and not in the HLA region. Nature 254:267 - Graessmann A, Graessmann M, Guhl E, Mueller C (1978) Quantitative correlation between simian virus $40 \mathrm{~T}$-antigen synthesis and late viral gene expression in permissive and non-permissive cells. J Cell Biol 77:R1 - Graessmann A, Wolf H, Bornkamm GW (1980) Expression of Epstein-Barr virus genes in different cell types after microinjection of viral DNA. Proc Natl Acad Sci USA 77:433 - Hellriegel KP, Diehl V, Krause $\mathrm{PH}$, Meier S, Blankenstein M, Busche W (1977) The significance of chromosomal findings for the differentiation between lymphoma and lymphoblastoid cell lines. In: Thierfelder S, Rodt $\mathrm{H}$, Thiel E (eds) Hematology and blood transfusion. Immunological diagnosis of leukemias and lymphomas. Springer, Berlin, p. 307 - Henle G, Henle W (1979) The virus as the etiologic agent of infectious mononucleosis. In: Epstein MA, Achong BG (eds) The Epstein-Barr virus. Springer, Berlin, p 297 - Jarvis JE, Ball G, Rickinson AB, Epstein MA (1974) Cytogenetic studies on human lymphoblastoid cell lines from Burkitt's lymphoma and other sources. Int J Cancer 14:716 - Jondal M, Klein G (1973) Surface markers on human B and T lymphocytes. II. Presence of Epstein-Barr virus (EBV) receptors on B lymphocytes. J Exp Med 138:1365 - Jondal M, Klein G, Oldstone M, Bokish V, Yefenof E (1976), Surface markers on human $B$ and $\mathrm{T}$ lymphocytes. VIII. Association between complement and Epstein-Barr virus (EBV) receptors on human lymphoid cells. Scand J Immunol 5:401 - Klein G (1979) The relationship of the virus to nasopharyngeal carcinoma. In: Epstein MA, Achong BG (eds) The Epstein-Barr virus. Springer, Berlin, p 339 - Klein E, Eskeland T, Inoue M, Strom R, Johansson B (1970) Surface immunoglobulin moieties on lymphoid cells. Exp Cell Res 62:133 - Klein G, Wiener F, Zech L, zur Hausen $H$, Reedman B (1974) Segregation of the EBV-determined nuclear antigen (EBNA) in somatic cell hybrids derived from the fusion of a mouse fibroblast and a human Burkitt line. Int J Cancer 14:54 - Klein 
G, Giovanella B, Westman A, Stehlin J, Mumford D (1975) An EBV-genome-negative cell line established from an American Burkitt lymphoma: Receptor characteristics, EBV infectability and permanent conversion into EBV-positive sublines by in vitro infection. Intervirology 5:319 - Klein $G$, Zeuthen J, Terasaki P, Billing R, Honig R, Jondal M, Westman A, Clements G (1976a) Inducibility of the Epstein-Barr virus (EBV) cycle and surface marker properties of EBV-negative lymphoma lines and their in vitro EBV-converted sublines. Int $\mathrm{J}$ Cancer 18:639 - Klein G, Clements G, Zeuthen J, Westman A (1976b) Somatic cell hybrid between human lymphoma lines. II. Spontaneous and induced patterns of the Epstein-Barr virus (EBV) cycle. Int J Cancer 17:71515 - Klein G, Terasaki P, Billing R, Honig R, Jondal M, Rosén A, Zeuthen J, Clements G (1977a) Somatic cell hybrids between human lymphoma lines. III. Surface markers. Int J Cancer 19:66 - Klein G, Clements G, Zeuthen J, Westman A (1977b) Spontaneous and induced patterns of the Epstein-Barr virus (EBV) cycle in a new set of somatic cell hybrids. Cancer Lett 3:91 - Klein G, Zeuthen J, Eriksson I, Terasaki P, Bernoco M, Rosén A, Masucci G, Povey S, Ber R (1980) Hybridization of a myeloid leukemia - derived human cell line (K562) with a human Burkitt's lymphoma line (P3HR-1). J Natl Cancer Inst 64:725 - Klein G, Luka J, Zeuthen J (1980) Epstein-Barr virus (EBV)-induced transformation and the role of the nuclear antigen (EBNA). Cold Spring Harbor Symp Quant Biol 44:253 - Koskimies S (1980) A human lymphoblastoid cell line producing specific antibody against Rh-D antigen. Scand J Immunol 11:73 - Kozbor D, Steinitz M, Klein G, Koskimies S, Mäkelä O (1979) Establishment of anti-TNP antibody producing human lymphoid lines by preselection for hapten binding followed by EBV transformation. Scand J Immunol 10:187 - Lenoir G, Berthelon MC, Faure MC, de Thé G (1976) Characterization of Epstein-Barr virus antigens. I. Biochemical analysis of the complement-fixing soluble antigen and relationship with Epstein-Barr virus - associated nuclear antigen. J Virol 17:672 - Luka J, Siegert W, Klein G (1977) Solubilization of the Epstein-Barr virus determined nuclear antigen and its characterization as a DNAbinding protein. J Virol 22:1 - Luka J, Lindahl T, Klein G (1978) Purification of the Epstein-Barr virus determined nuclear antigen from Epstein-Barr virus transformed human lymphoid cell lines. J Virol 27:604 - Luka J, Jörnvall $H$, Klein $G$ (to be published) Purification and biochemical characterization of the Epstein-Barr virus (EBV) determined nuclear antigen (EBNA) and and an associated protein with a 53K subunit. - Manolov G, Manolova $Y$ (1972) marker band in one chromosome 14 from Burkitt lymphomas. Nature 237:33 - Matsuoka Y, Takahashi M, Yagi Y, Moore GE, Pressman (1968) Synthesis and secretion of immunoglobulins by established cell lines of human hematopoietic origin.
J Immunol 101:1111 - McCaw KB, Hecht F, Harnden DG, Teplitz RJ (1975) Somatic rearrangement of chromosome 14 in human lymphocytes. Proc Natl Acad Sci USA 72:2071 - McConnell I, Klein G, Lint TF, Lachmann PJ (1978) Activation of the alternative complement pathway by human $B$ cell lymphoma lines is associated with EpsteinBarr virus transformation of the cells. Eur J. Immunol 8:453 - McCormick F, Harlow E (1980) Association of a murine 53,000-dalton phosphoprotein with simian virus 40 large- $T$ antigen in transformed cells. J Virol 34:213 - Menezes J, Leibold W, Klein G, Clements G (1975) Establishment of an Epstein-Barr virus (EBV)-negative lymphoblastoid $B$ cell line (BJA-B) from an exceptional, EBV-genome-negative African Burkitt's lymphoma. Biomedicine 22:276 - Moar MH, Ber R, Klein G, Westman A, Eriksson I (1978) Somatic cell hybrids between human lymphoma lines. V. IUdR inducibility and P3HR-1 superinfectability of Daudi/HeLa (DAD) and Daudi/P3HR-1 (DIP-1) cell lines. Int J Cancer 22:669 - Montagnier L, Gruest J (1979) Cell-density-dependence for growth in agarose of two human lymphoma lines and its decrease after Epstein-Barr virus conversion. Int $\mathbf{J}$ Cancer 23:71 - Nilsson $\mathrm{K}$ (1978) Established human lymphoid cell lines as models for B-lymphocyte differentiation. In: Serrou B, Rosenfeld C (eds) Human lymphocyte differentiation: Its application to cancer. North-Holland, Amsterdam, p 307 - Nilsson K, Pontén J (1975) Classification and biological nature of established human hematopoietic cell lines. Int J Cancer 15:321 - Nilsson K, Giovanella BC, Stehlin JS, Klein G (1977) Tumorigenicity of human hematopoietic cell lines in athymic nude mice. Int J Cancer 19:337 - Nyormoi O, Klein G, Adams A, Dombos L (1973) Sensitivity to EBV superinfection and IUdR inducibility of hybrid cells formed between a sensitive and a relatively resistant Burkitt lymphoma cell line. Int J Cancer 12:396 - Oliver N, Francke U, Pellegrino MA (1978) Regional assignment of genes for mannose phosphate isomerase, pyruvate kinase 3 , and $\beta_{2}$-microglobulin expression on human chromosome 15 by hybridization of cells from a $t(15 ; 22)$ $(\mathrm{q} 14 ; \mathrm{q} 13.3)$ translocation carrier. Cytogenet Cell Genet 22:506 - Plesner T (1978) Lymphocyte associated $\beta_{2}$-microglobulin studied by crossed radioimmunoelectrophoresis. Scand J Immunol 8:363 - Pope JH (1979) Transformation by the virus in vitro. In: Epstein MA, Achong BG (eds) The Epstein-Barr virus. Springer, Berlin p 205 - Povey S, Jeremiah S, Arthur E, Ber R, Fialkow PJ, Gardiner E, Goodfellow PN, Karande A, Quintero M, Steel $\mathrm{CM}$, Zeuthen J (to be published) Deficiency of malic enzyme: A possible marker for malignancy in lymphoid cells Ann Hum Genet - Reedman B, Klein G (1973) Cellular localization of an Epstein-Barr virus (EBV)-associated complement-fixing antigen in producer and non-producer lymphoblastoid cell lines. Int J Cancer 11:499 - Rosén A, Clements G, Klein G, Zeuthen J (1977) Double immunoglobulin 
production in cloned somatic cell hybrids between two human lymphoid lines. Cell 11:139 - Rutherford TR, Clegg JB, Weatherall DJ (1979) K562 human leukaemic cells synthesize embryonic haemoglobin in response to haemin. Nature 280:164 - Singer PA, Williamson AR (1979) A novel interaction involving a polypeptide chain (P33) in covalent linkage with IgM on the surface of a Burkitt lymphoma cell line (Daudi). Eur J Immunol 9:224 - Steel CM, Woodward MA, Davidson C, Philipson J, Arthur E (1977) Non-random chromosome gains in human lymphoblastoid cell lines. Nature 270:349 - Steinitz M, Klein G (1975) Comparison between growth characteristics of an Epstein-Barr virus (EBV)-genome negative lymphoma line and its EBV-converted subline in vitro. Proc Natl Acad Sci USA 72:3518 - Steinitz M, Klein G (1976) EpsteinBarr virus (EBV)-induced change in saturation density and serum dependence of established, EBVnegative lymphoma lines in vitro. Virology 70:570 - Steinitz M, Klein G (1977) Further studies on the differences in serum dependence in EBV-negative lymphoma lines and their in vitro converted, virusgenome carrying sublines. Eur J Cancer 13:1269 - Steinitz M, Klein G, Koskimies S, Mäkelä O (1977) EB virus-induced B-lymphocyte cell lines producing specific antibody. Nature 269:420-Steinitz M, Koskimies S, Klein G, Mäkelä O (1978) Establishment of specific antibody producing human cell lines by antigen preselection and EBV transformation. Curr Top Microbiol Immunol 81:156-Steinitz M, Seppälä I, Klein G, Koskimies S, Mäkelä $O$ (1979) Immunobiology 156:41 - Steinitz M, Izak G, Cohen S, Ehrenfeld M, Flechner J (to be published) Continuous production of rheumatoid factor by in vitro EBV-transformed lymphocytes. Nature - Tanaka A, Nonoyama M, Glaser R (1977) Transcription of latent Epstein-Barr virus genomes in human epithelial/Burkitt hybrid cells. Virology 82:63 - Tjian R, Fey G, Graessmann A (1978) Biological activity of purified simian virus $40 \mathrm{~T}$ antigen proteins. Proc Natl Acad Sci USA 75:1279 - Van den Berghe, H, Parloir C, Gosseye S, Englebienne V, Cornu G, Sokal G (1979) Variant translocation in Burkitt lymphoma Cancer Genet Cytogenet 1:9 - Van Furth R, Gorter H, Nadkarni JS, Klein E, Clifford P (1972) Synthesis of immunoglobulins by biopsied tissues and cell lines from Burkitt's lymphoma. Immunology 22:847 - Yefenof E, Klein G (1976) Difference in antibody induced redistribution of membrane IgM in EBV-genome free and EBV-positive human lymphoid cells. Exp Cell Res 99:175 - Yefenof E, Klein G, Ben-Bassat $H$, Lundin L (1977) Differences in the ConA-induced redistribution and agglutination patterns of EBV genome-free and EBV-carrying human lymphoma lines. Exp Cell Res 108:185 - Zech L, Haglund U, Nilsson K, Klein G (1976) Characteristic chromosomal abnormalities in biopsies and lymphoid cell lines from patients with Burkitt and non-Burkitt lymphomas. Int J Cancer 17:47 - Zeuthen J, Nilsson K (1976) Hybridization of a human myeloma permanent cell line with mouse cells. Cell Differ 4:355 - Zeuthen J, Friedrich U, Rosén A, Klein E (1977) Structural abnormalities in chromosome 15 in cell lines with reduced expression of Beta-2 microglobulin. Immunogenetics 4:567 - Zeuthen J, Klein G, Ber R, Masucci G, Bisballe S, Povey S, Terasaki P, Ralph $\mathrm{P}$ (to be published) Human lymphoma/lymphoma and lymphoma/leukemia hybrids. I. Isolation, characterization, cell surface and B-cell marker studies. J Natl Cancer Inst - Zur Hausen H, Bornkamm GW, Schmidt R, Hecker E (1979) Tumor initiators and promotors in the induction of Epstein-Barr virus. Proc Natl Acad Sci USA 76:782 